\title{
Monetary Policy Implications of Electronic Currency: \\ An Empirical Analysis
}

\author{
Christopher Fogelstrom
}

Ann L. Owen*

Hamilton College

February 2004

\begin{abstract}
Using the 2001 Survey of Consumer Finances, we find evidence that electronic currency is not a substitute for money held in checking accounts although it is associated with holding lower balances in savings accounts. These findings allay concerns that private sector issuance of electronic currency will inhibit the ability of central banks to conduct monetary policy.
\end{abstract}

JEL Codes: E41, E52, E61

key words: monetary policy, money demand, electronic currency

*Corresponding author: aowen@,hamilton.edu, Hamilton College Economics Department, 198 College Hill Road, Clinton, NY 13323. Phone: 315-859-4419, fax: 315-859-4477. We are grateful to Julio Videras and Stephen Wu for helpful comments. 


\section{Introduction}

The development of electronic currency products by the private sector has been a closely watched phenomena by central banks in developed countries. ${ }^{1}$ Although still in a developing stage, private sector issuance of electronic currency poses potential problems for policy makers. Substitution of private sector liabilities that can function like central bank liabilities could reduce the demand for these liabilities and complicate the conduct of monetary policy.

While most central banks have lowered the importance of the monetary aggregates in formulating policy, the existence of a demand for central bank liabilities is crucial to the ability of the central bank to conduct monetary policy under current practice. Friedman (2000) argues that, at the margin, electronic currency could "decouple" the interest rate that the central bank sets from the rates that are important for determining economic activity. Woodford (2000) suggests that even with widespread use of electronic currency, the central bank could still control interest rates, albeit through different operating procedures that may require it to lend or borrow much larger quantities than is done today. Freedman (2000) provides a similar view. Rolnick (1999) takes a different tack and questions the impact that electronic currency may have on the uniformity of the medium of exchange. Although these authors disagree on the extent of the impact of electronic currency, at the core of all of these arguments is the premise that the impact of electronic currency depends on its effect on the demand for central bank liabilities. Electronic currency's impact on money demand is an empirical question which we take up in this paper.

${ }^{1}$ Evidence for this point can be seen in the numerous speeches, publications, and reports by economists and officials at central banks and international banking agencies. See, for example, Bank for International Settlements (1996), European Central Bank (1998), Meyer (2001), or Organisation for Economic Cooperation and Development (2002). 
Admittedly, we are only able to study the behavior of early adopters of smartcards, an electronic medium of exchange and store of value. However, if usage among this group indicates that electronic currency and checking accounts are substitutes, a significant problem may occur for policy makers if adoption spreads through a larger population. Our results, however, suggest the opposite: smartcard use is associated with holding higher checking account balances. Therefore, even if electronic currency usage becomes widespread, the conduct of monetary policy is not in jeopardy.

Our work is related to Kennickel and Kwast (1997) who have studied the determinants of smartcard ownership and is also more broadly related to the literature on the demand for credit cards and their impact on money demand. Duca and Whitesell (1995) investigate the impact of credit card ownership on money demand, while Calem and Mester (1995), Brito and Hartley (1995), and Castranova and Hagstrom (2004) investigate the demand for credit cards more generally. A key difference between credit cards and smartcards that will simplify our study, however, is that credit cards are both a means of payment and a means of borrowing. Because smartcards are prepaid, they are not associated with borrowing.

Our paper is organized in the following 3 sections. Section 2 describes our methodology and data, Section 3 presents the results, and Section 4 concludes.

\section{Methodology and Data}

In order to assess the impact of electronic currency on the demand for central bank liabilities, we follow the approach of Duca and Whitesell (1995). We model the demand for checking account balances as a function of demographic characteristics; qualitative characteristics that may be associated with higher savings; wealth/income variables; and 
smartcard ownership. Individuals, however, will only have checking accounts if their desired checking account holdings are positive. Thus, our structural model can be written

$$
\begin{aligned}
& \mathrm{M}_{\mathrm{i}}^{*}=\beta \mathrm{X}_{\mathrm{i}}+\mathrm{u}_{\mathrm{i}} \\
& \mathrm{A}_{\mathrm{i}}=1 \text { if } \mathrm{M}_{\mathrm{i}}^{*}>0 \\
& \mathrm{~A}_{\mathrm{i}}=0 \text { if } \mathrm{M}_{\mathrm{i}}^{*} \leq 0 \\
& \operatorname{Prob}\left(\mathrm{A}_{\mathrm{i}}=1\right)=\Phi\left(\mathrm{X}_{\mathrm{i}} \beta\right)
\end{aligned}
$$

where $M^{*}$ is a latent variable denoting the desired checking account balance, $X$ is a vector of individual characteristics, $\mathrm{A}$ is a binary variable indicating checking account ownership, and $u$ is mean zero, normal disturbance term. When desired balances are not positive, $\mathrm{M}^{*} \leq 0$, individual $i$ does not have a checking account $\left(\mathrm{A}_{\mathrm{i}}=0\right)$ and $\mathrm{M}^{*}$ is not observed. Thus, we estimate

$$
\mathrm{M}_{\mathrm{i}}=\gamma_{1} \text { SMARTCARD }+\gamma_{2} Z_{\mathrm{i}}+\epsilon_{\mathrm{i}}
$$

where $\mathrm{M}$ is observed checking account balances, SMARTCARD is a dummy variable which equals one if the household owns a smartcard and $Z_{\mathrm{i}}$ is a vector of control variables. We estimate Equation 1 via maximum likelihood using a Heckman selection model.

We focus our analysis on checking account balances as this form of money is most directly related to reserves held at the central bank. Policy concerns would arise if the coefficient on SMARTCARD were negative and significant, indicating that smartcard ownership is associated with lower checking account balances and suggesting that increased usage of this medium exchange would result in lower reserve balances. We also include the variable SMARTCARD in the probit estimation of $\mathrm{A}_{\mathrm{i}}$, account ownership, for similar reasoning: If smartcard ownership is associated with a reduced probability of owning a checking account, usage of electronic currency is likely to decrease the demand for checking accounts and, 
ultimately, central bank liabilities.

The data we use come from the 2001 Survey of Consumer Finances (SCF), a triennial survey conducted by the Federal Reserve. This data contains a wealth of detailed information about household finances including account balances, income, employment, and attitudes. We use this data to create three broad categories of control variables, $Z_{i}$, that may impact money holdings: 1) wealth and income variables, 2) qualitative characteristics that may be associated with checking account holdings such as those that could cause higher precautionary demand or indicate greater financial sophistication, and 3) demographic characteristics. Wealthier, high income individuals would be expected to have higher checking account balances as they are likely to have higher transactions needs, individuals who have a greater precautionary motives may also keep greater reserves in their checking account, and financial sophistication is likely related to electronic currency usage and could also influence checking account balances. Finally, demographic characteristics such as age and education may influence checking account balances if these characteristics are associated with either greater needs for liquidity or differing abilities to maintain liquidity.

Variables in the wealth and income category are the natural logs of total assets and of labor income. There are several variables in the precautionary demand/financial sophistication category. The first is an ordinal variable indicating how much risk people report taking in financial decision making (on a scale of 1 to 4 with 4 being the least risk). Another variable in this category is a dummy variable indicating if the household consults a professional advisor for borrowing and/or savings decisions. Other measures of financial sophistication include separate dummy variables indicating credit card ownership, using online resources to make financial 
decisions, stock ownership, and the number of financial institutions used. Variables in the demographic characteristic category include dummy variables for married households, if the household head or the spouse is unemployed, a student, on welfare, is black, and dummy variables for the highest level of education received by the head or spouse. ${ }^{2}$ We also control for the age of the head of the household as well as the natural log of the number of people in the household. ${ }^{3}$

Descriptive statistics and variable definitions are presented in Table 1. After dropping households from our sample that have a net worth greater than \$2 million or checking account balances greater than $\$ 200,000$, we have data for 2,694 households. A little over 3 percent of our sample owns a smartcard, defined in the SCF as a "a type of payment card containing a computer chip which is set to hold a sum of money. As the card is used, purchases are subtracted from the sum." About 80 percent of our sample owns a credit card, and ninety percent of the sample owns a checking account, with a mean holding of $\$ 5,514$. Of course, even though we have dropped the very wealthy households from our sample, the distribution of financial assets is still skewed: the median checking account balance in our sample is lower at $\$ 1,700$. In our estimations, we attempt to reduce the influence of the wealthiest people in our sample by taking the natural log of all financial variables, and we report all results after correcting standard errors for hetereoskedasticity.

${ }^{2}$ Specifically, to determine how educated the "household" is, we use the education level of the most educated person in the household.

${ }^{3}$ In most cases in the SCF, the male is arbitrarily coded as the head of the household so a dummy for the sex of the head of the household is not meaningful. 


\section{Results}

Before presenting the results from the Heckman selection model, we first present the coefficients from probit estimations for checking account and smartcard ownership in Table 2. While these results indicate that we have found no evidence that smartcard ownership affects checking account ownership, many of the other variables we have included enter the checking account estimation in expected ways. Households with more assets, more income, fewer people and more education are more likely to have checking accounts. Furthermore, several of our variables measuring financial sophistication also have explanatory power for checking account ownership. Households that own credit cards, get financial information online, own stock, and do business with more financial institutions are also more likely to have checking accounts. In the smartcard probit reported in column 2 of Table 2, we find only two significant variables indicating smartcard ownership. Individuals who use online sources for financial information are more likely to have a smartcard as well as people on welfare. While the result that more sophisticated households are more likely to have smartcards is not surprising, the fact that households on welfare also have increased probability of owning a smartcard may be. However, it can be explained by the fact that most food stamp and WIC benefits are paid through Electronic Benefits Transfer (EBT). ${ }^{4}$

The results of our main estimation of checking account balances using the Heckman selection procedure appear in Table 3. We report both the results from the probit estimation of the determinants of owning a checking account and the second step in which the determinants of

${ }^{4}$ Technically, not all EBT cards are based on the computer chip technology, but the magnetic stripe cards effectively perform the same services as the computer chip cards and the distinction is not important for this study. 
the log of checking account balances are estimated after correcting for selection bias. In columns 1 and 2, we report results using only the wealth and income variables as independent variables, in columns 3 and 4, we add demographic variables and in columns 5 and 6 we add the variables intending to measure precautionary demand and financial sophistication. Focusing on columns 5 and 6 which present the most complete set of independent variables, we find no evidence that smartcard ownership affects checking account ownership (column 5), but we do find evidence that smartcard ownership is associated with an increase in checking account balances. This conclusion is robust to the three different specifications reported. The magnitude of the effect is notable. The average value of $\ln$ (checking account balances) is 7.4. Results in Column 6 indicate that smartcard ownership increases this value by .270 . Evaluated at the average, this translates into an increase of $\$ 507$ (a little less than 10 percent of the average holding). Most of the other variables reported in columns 5 and 6 of Table 3 enter with expected signs. Wealthier and higher income households are both more likely to have a checking account and hold higher balances. Unemployed households and those on welfare hold lower checking account balances as well as those with more people in the household. More education is associated with higher balances as well as greater age. Finally, those that may have a greater savings motive as indicated by risk aversion or more financial sophistication as measured by use of a professional advisor, online information sources for financial decisions, credit card ownership, stock ownership, or the number of financial institutions with which they interact are also more likely to have higher checking account balances. Somewhat surprisingly, students hold more money in checking accounts, however, this result could be explained by the fact that students have greater needs for liquidity, after conditioning on their income. Although not 
reported in Table 3, we also verified that our results for checking account balances are robust to using OLS without correcting for selection bias.

The fact that we find that users of electronic currency actually hold higher checking account balances may at first seem counterintuitive. However, a plausible explanation for this behavior is that smartcard owners do not view smartcard balances as substitutes for balances held in checking accounts, and therefore have not adjusted their checking account deposit behavior. To the extent that smartcards are used for transactions purposes, smartcard users will then make fewer withdrawals from their checking accounts and thus have higher average balances. If this were the case, we would expect that smartcard users would have lower balances in other liquid accounts because they hold higher transactions balances (smartcard balances + checking account balances.)

To find evidence for this hypothesis, we replicate the estimations in Table 3 using savings account ownership and savings account balances instead of checking account ownership and checking account balances. The results to this exercise are presented in Table 4. Parallel to our results on checking accounts, we find no evidence that smartcard ownership affects savings account ownership, but the negative and significant coefficient on savings account balances on all three specifications provide evidence that smartcard users hold lower savings account balances. Thus, it appears that in their current form, smartcards are substitutes for savings but not checking account balances. Because savings account balances are less directly linked to reserves held by banks, this result allays concerns that electronic currency will interfere with the conduct of monetary policy. 


\section{Conclusion}

Private sector issuance of electronic currency is a concern for policy makers if electronic currency reduces the demand for central bank liabilities. Our work suggests, however, that electronic currency is not a substitute for money held in checking accounts. Rather, households who use electronic currency hold higher transactions balances and lower savings balances. Therefore, even if usage of electronic currency becomes more widespread, we find no evidence that it will interfere with the conduct of monetary policy. An important caveat to our study is that we are only able to study usage of electronic currency in its current form. Should electronic currency evolve and take on new functionality, further study would be warranted. 


\section{References}

Bank for International Settlements, 1996, "Implications for Central Banks of the Development of Electronic Money," Basle.

Brito, Dagobert L., and Peter R. Hartley, 1995, "Consumer Rationality and Credit Cards," Journal of Political Economy 103(2): 400-433.

Calem, Paul S. and Loretta J. Mester, 1995, "Consumer Behavior and the Stickiness of CreditCard Interest Rates" American Economic Review 85(5): 1327-36.

Castranova, Edward and Paul Hagstrom, 2004, "The Demand for Credit Cards: Evidence from the Survey of Consumer Finances" Economic Inquiry 42(2): 304-318.

Duca, John V. And William C. Whitesell, 1995, "Credit Cards and Money Demand: A Crosssectional Study," Journal of Money Credit and Banking 27(2): 604-623.

European Central Bank, 1998, "Report On Electronic Money,” Frankfurt.

Freedman, Charles, 2000, "Monetary Policy Implementation: Past, Present, Future: Will the Advent of Electronic Money Lead to the Demise of Central Banking?" International Finance $3(2): 211-27$.

Friedman, Benjamin M., 2000, "Decoupling at the Margin: The Threat to Monetary Policy from the Electronic Revolution in Banking,” NBER Working Paper \#7955.

Kennickell, Arthur, B. And Myron L. Kwast, 1997, "Who Uses Electronic Banking? Results from the 1995 Survey of Consumer Finances," Federal Reserve Board of Governors mimeo.

Meyer, Laurence H., 2001, “The Future of Money and Monetary Policy,” Remarks by Governor Laurence H. Meyer, December 5, 2001, Swarthmore, Pennsylvania.

Organisation for Economic Cooperation and Development, 2002, “The Future of Money," Paris.

Rolnick, Arthur J., 1999, "Thought on the Future of Payments and Central Banking: Maintaining a Uniform (Electronic) Currency," Journal of Money Credit and Banking 31(3): 674-676.

Woodford, Michael, 2000, "Monetary Policy in a World without Money," International Finance 3(2): 229-60. 
Table 1: Descriptive Statistics and Variable Definitions

\begin{tabular}{|c|c|c|c|}
\hline Variable & Mean & S.D. & Definition \\
\hline TOTAL CHECKING BALANCES & 5,614 & 13,876 & Balance in all checking accounts \\
\hline SMARTCARD & .033 & .178 & $=1$ if own a smartcard \\
\hline CHECKING ACCOUNT & .891 & .311 & $=1$ if own a checking account \\
\hline \multicolumn{4}{|l|}{ Financial Variables } \\
\hline ASSETS & 323,741 & 457,864 & Total household assets \\
\hline LABOR INCOME & 58,697 & 67,551 & Household labor income \\
\hline \multicolumn{4}{|l|}{ Demographics } \\
\hline AGE & 43.3 & 12.9 & Age of head of household \\
\hline BLACK & .133 & .339 & $=1$ if black \\
\hline MARRIED & .563 & .496 & $=1$ if married \\
\hline HOUSEHOLD SIZE & 2.66 & 1.44 & Number of people in household \\
\hline HIGHSCHOOL & .516 & .499 & $\begin{array}{l}=1 \text { if highest level of education obtained by most } \\
\text { educated household member is high school }\end{array}$ \\
\hline COLLEGE & .227 & .419 & $\begin{array}{l}=1 \text { if highest level of education obtained by most } \\
\text { educated household member is college }\end{array}$ \\
\hline GRADUATE & .178 & .382 & $\begin{array}{l}=1 \text { if highest level of education obtained by most } \\
\text { educated household member is graduate school }\end{array}$ \\
\hline STUDENT & .018 & .134 & $=1$ if student \\
\hline UNEMPLOYED & .028 & .165 & $=1$ if head or spouse is unemployed \\
\hline WELFARE & .039 & .193 & $=1$ if receive welfare payments \\
\hline \multicolumn{4}{|l|}{ Savings Predictors } \\
\hline AVERSE & 1.99 & .858 & $\begin{array}{l}\text { Ordinal variable indicating amount of financial risk } \\
\text { willing to take } 1=\text { risk loving, } 4=\text { risk averse }\end{array}$ \\
\hline PROFESSIONAL ADVICE & .590 & .492 & $=1$ if seek professional financial advice \\
\hline CREDITCARD & .798 & .401 & $=1$ if own a credit card \\
\hline ONLINE & .309 & .463 & $=1$ if obtain financial information online \\
\hline STOCK & .224 & .417 & $=1$ if own stock \\
\hline INSTITUTIONS & 3.51 & 2.67 & Number of financial institutions used \\
\hline
\end{tabular}

Notes: 2,714 observations. Households with net worth greater than $\$ 2$ million and with total checking account balances greater than $\$ 200,000$ were excluded from the sample. All financial variables are in current (2001) dollars. 
Table 2: Probit Results for Checking Account and Smartcard Ownership

\begin{tabular}{|c|c|c|}
\hline & \multicolumn{2}{|c|}{ Dependent Variable } \\
\hline & CHECKING ACCOUNT & SMARTCARD \\
\hline SMARTCARD & $\begin{array}{l}-.234 \\
(.266)\end{array}$ & \\
\hline LN(ASSET) & $\begin{array}{l}.095 * * \\
(.020)\end{array}$ & $\begin{array}{l}.001 \\
(.034)\end{array}$ \\
\hline LN(LABOR INCOME) & $\begin{array}{l}.106 * * \\
(.051)\end{array}$ & $\begin{array}{l}.100 \\
(.063)\end{array}$ \\
\hline AGE & $\begin{array}{l}.005 \\
(.003)\end{array}$ & $\begin{array}{l}.005 \\
(.004)\end{array}$ \\
\hline BLACK & $\begin{array}{l}-.340 * * \\
(.113)\end{array}$ & $\begin{array}{l}.195 \\
(.140)\end{array}$ \\
\hline MARRIED & $\begin{array}{l}.152 \\
(.116)\end{array}$ & $\begin{array}{l}-.166 \\
(.129)\end{array}$ \\
\hline LN(HOUSEHOLD SIZE) & $\begin{array}{l}-.255^{* *} \\
(.094)\end{array}$ & $\begin{array}{l}.091 \\
(.103)\end{array}$ \\
\hline HIGHSCHOOL & $\begin{array}{l}.307 * * \\
(.121)\end{array}$ & $\begin{array}{l}.197 \\
(.211)\end{array}$ \\
\hline COLLEGE & $\begin{array}{l}.873 * * \\
(.208)\end{array}$ & $\begin{array}{l}.064 \\
(.242)\end{array}$ \\
\hline GRADUATE & $\begin{array}{l}1.12 * * \\
(.325)\end{array}$ & $\begin{array}{l}.328 \\
(.233)\end{array}$ \\
\hline STUDENT & $\begin{array}{l}.356 \\
(.360)\end{array}$ & \\
\hline UNEMPLOYED & $\begin{array}{l}-.176 \\
(.202)\end{array}$ & \\
\hline WELFARE & $\begin{array}{l}-.151 \\
(.173)\end{array}$ & $\begin{array}{l}.627 * * \\
(.243)\end{array}$ \\
\hline AVERSE & $\begin{array}{l}.063 \\
(.065)\end{array}$ & $\begin{array}{l}.011 \\
(.060)\end{array}$ \\
\hline PROFESSIONAL ADVICE & $\begin{array}{l}.097 \\
(.092)\end{array}$ & $\begin{array}{l}-.033 \\
(.097)\end{array}$ \\
\hline CREDITCARD & $\begin{array}{l}.533 * * \\
(.095)\end{array}$ & $\begin{array}{l}.025 \\
(.135)\end{array}$ \\
\hline ONLINE & $\begin{array}{l}.403 * * \\
(.149)\end{array}$ & $\begin{array}{l}.188^{*} \\
(.105)\end{array}$ \\
\hline STOCK & $\begin{array}{l}-.300 * \\
(.176)\end{array}$ & $\begin{array}{l}.055 \\
(.125)\end{array}$ \\
\hline INSTITUTIONS & $\begin{array}{l}.323 * * \\
(.048)\end{array}$ & $\begin{array}{l}.005 \\
(.019)\end{array}$ \\
\hline
\end{tabular}

$* *$ significant at $5 \%, *$ significant at $10 \%$. Robust standard errors are in parentheses. All estimations include a constant. Note that student and unemployed were dropped from the estimation as they predict failure perfectly. 
Table 3: Determinants of Checking Account Ownership and Balances

\begin{tabular}{|c|c|c|c|c|c|c|}
\hline & $\begin{array}{c}\text { (1) } \\
\text { Ownership }\end{array}$ & $\begin{array}{c}\text { (2) } \\
\text { Balance }\end{array}$ & $\begin{array}{c}\text { (3) } \\
\text { Ownership }\end{array}$ & $\begin{array}{c}(4) \\
\text { Balance }\end{array}$ & $\begin{array}{c}(5) \\
\text { Ownership }\end{array}$ & $\begin{array}{c}\text { (6) } \\
\text { Balance }\end{array}$ \\
\hline SMARTCARD & $\begin{array}{l}-.287 \\
(.201)\end{array}$ & $\begin{array}{l}.338 * * \\
(.130)\end{array}$ & $\begin{array}{l}-.214 \\
(.226)\end{array}$ & $\begin{array}{l}.303 * * \\
(.128)\end{array}$ & $\begin{array}{l}-.233 \\
(.265)\end{array}$ & $\begin{array}{l}.270 * * \\
(.126)\end{array}$ \\
\hline LN(ASSETS) & $\begin{array}{l}.256 * * \\
(.017)\end{array}$ & $\begin{array}{l}.492 * * \\
(.020)\end{array}$ & $\begin{array}{l}.213 * * \\
(.019)\end{array}$ & $\begin{array}{l}.423 * * \\
(.022)\end{array}$ & $\begin{array}{l}.095 * * \\
(.019)\end{array}$ & $\begin{array}{l}.348 * * \\
(.024)\end{array}$ \\
\hline LN(LABOR INCOME) & $\begin{array}{l}.250 * * \\
(.037)\end{array}$ & $\begin{array}{l}.220 * * \\
(.041)\end{array}$ & $\begin{array}{l}.191 * * \\
(.047)\end{array}$ & $\begin{array}{l}.207 * * \\
(.042)\end{array}$ & $\begin{array}{l}.105 * * \\
(.051)\end{array}$ & $\begin{array}{l}.180 * * \\
(.041)\end{array}$ \\
\hline STUDENT & & & $\begin{array}{l}.600 \\
(.407)\end{array}$ & $\begin{array}{l}.419^{*} \\
(.190)\end{array}$ & $\begin{array}{l}.354 \\
(.361)\end{array}$ & $\begin{array}{l}.334 * \\
(.191)\end{array}$ \\
\hline UNEMPLOYED & & & $\begin{array}{l}-.171 \\
(.205)\end{array}$ & $\begin{array}{l}-.754 * * \\
(.274)\end{array}$ & $\begin{array}{l}-.173 \\
(.203)\end{array}$ & $\begin{array}{l}-.795 * * \\
(.268)\end{array}$ \\
\hline WELFARE & & & $\begin{array}{l}-.221 \\
(.175)\end{array}$ & $\begin{array}{l}-.675 * * \\
(.301)\end{array}$ & $\begin{array}{l}-.162 \\
(.174)\end{array}$ & $\begin{array}{l}-.677^{*} \\
(.289)\end{array}$ \\
\hline MARRIED & & & $\begin{array}{l}.091 \\
(.106)\end{array}$ & $\begin{array}{l}-.070 \\
(.086)\end{array}$ & $\begin{array}{l}.148 \\
(.116)\end{array}$ & $\begin{array}{l}-.081 \\
(.085)\end{array}$ \\
\hline $\begin{array}{l}\text { LN(HOUSEHOLD } \\
\text { SIZE) }\end{array}$ & & & $\begin{array}{l}-.211 * * \\
(.088)\end{array}$ & $\begin{array}{l}-.276 * * \\
(.072)\end{array}$ & $\begin{array}{l}-.251 * * \\
(.095)\end{array}$ & $\begin{array}{l}-.235 * * \\
(.073)\end{array}$ \\
\hline BLACK & & & $\begin{array}{l}-.327 * * \\
(.104)\end{array}$ & $\begin{array}{l}-.009 \\
(.096)\end{array}$ & $\begin{array}{l}-.339 * * \\
(.113)\end{array}$ & $\begin{array}{l}-.008 \\
(.094)\end{array}$ \\
\hline $\begin{array}{l}\text { HIGH } \\
\text { SCHOOL }\end{array}$ & & & $\begin{array}{l}.501 * * \\
(.117)\end{array}$ & $\begin{array}{l}.230 \\
(.165)\end{array}$ & $\begin{array}{l}.304 * * \\
(.121)\end{array}$ & $\begin{array}{l}.131 \\
(.162)\end{array}$ \\
\hline COLLEGE & & & $\begin{array}{l}1.31 * * \\
(.189)\end{array}$ & $\begin{array}{l}.647 * * \\
(.172)\end{array}$ & $\begin{array}{l}.868 * * \\
(.209)\end{array}$ & $\begin{array}{l}.446 * * \\
(.170)\end{array}$ \\
\hline $\begin{array}{l}\text { GRADUATE } \\
\text { SCHOOL }\end{array}$ & & & $\begin{array}{l}1.50 * * \\
(.296)\end{array}$ & $\begin{array}{l}.868 * * \\
(.175)\end{array}$ & $\begin{array}{l}1.12 * * \\
(.325)\end{array}$ & $\begin{array}{l}.648 * * \\
(.172)\end{array}$ \\
\hline AGE & & & $\begin{array}{l}.003 \\
(.003)\end{array}$ & $\begin{array}{l}.008 * * \\
(.003)\end{array}$ & $\begin{array}{l}.005 \\
(.003)\end{array}$ & $\begin{array}{l}.011 * * \\
(.003)\end{array}$ \\
\hline RISK AVERSE & & & & & $\begin{array}{l}.065 \\
(.061)\end{array}$ & $\begin{array}{l}.089 * * \\
(.037)\end{array}$ \\
\hline CREDIT CARD & & & & & $\begin{array}{l}.533 * * \\
(.096)\end{array}$ & $\begin{array}{l}.187 * \\
(.097)\end{array}$ \\
\hline STOCK & & & & & $\begin{array}{l}-.295^{*} \\
(.178)\end{array}$ & $\begin{array}{l}.243 * * \\
(.077)\end{array}$ \\
\hline ONLINE & & & & & $\begin{array}{l}.402 * * \\
(.150)\end{array}$ & $\begin{array}{l}.086 * * \\
(.059)\end{array}$ \\
\hline INSTITUTIONS & & & & & $\begin{array}{l}.323 * * \\
(.049)\end{array}$ & $\begin{array}{l}.040 * * \\
(.012)\end{array}$ \\
\hline $\begin{array}{l}\text { PROFESSIONAL } \\
\text { ADVICE }\end{array}$ & & & & & $\begin{array}{l}.099 \\
(.092)\end{array}$ & $\begin{array}{l}.175 * * \\
(.061)\end{array}$ \\
\hline
\end{tabular}

** significant at $5 \%$ *significant at $10 \%$ (notes to Table 3 continued on next page) 
Notes to Table 3 (cont.)

Columns 1 and 2, 3 and 4, 5 and 6 are estimated jointly using the Heckman maximum likelihood procedure. Robust standard errors are in parentheses. All estimations include a constant. The dependent variable in columns 1,3, and 5 is a binary variable indicating checking account ownership. The dependent variable in columns 2,4, and 6 is the natural log of total checking account balances. 
Table 4: Determinants of Savings Account Ownership and Balances

\begin{tabular}{|c|c|c|c|c|c|c|}
\hline & $\begin{array}{c}\text { (1) } \\
\text { Ownership }\end{array}$ & $\begin{array}{c}\text { (2) } \\
\text { Balance }\end{array}$ & $\begin{array}{c}\text { (3) } \\
\text { Ownership }\end{array}$ & $\begin{array}{c}\text { (4) } \\
\text { Balance }\end{array}$ & $\begin{array}{c}(5) \\
\text { Ownership }\end{array}$ & $\begin{array}{c}\text { (6) } \\
\text { Balance }\end{array}$ \\
\hline SMARTCARD & $\begin{array}{l}-.123 \\
(.143)\end{array}$ & $\begin{array}{l}-.547 * \\
(.292)\end{array}$ & $\begin{array}{l}-.114 \\
(.143)\end{array}$ & $\begin{array}{l}-.511 * \\
(.287)\end{array}$ & $\begin{array}{l}-.133 \\
(.146)\end{array}$ & $\begin{array}{l}-.528 * \\
(.281)\end{array}$ \\
\hline LN(ASSETS) & $\begin{array}{l}.115 * * \\
(.011)\end{array}$ & $\begin{array}{l}.588 * * \\
(.031)\end{array}$ & $\begin{array}{l}.117 * * \\
(.014)\end{array}$ & $\begin{array}{l}.508 * * \\
(.036)\end{array}$ & $\begin{array}{l}.066 * * \\
(.015)\end{array}$ & $\begin{array}{l}.474 * * \\
(.039)\end{array}$ \\
\hline LN(LABOR INCOME) & $\begin{array}{l}.079 * * \\
(.030)\end{array}$ & $\begin{array}{l}.111 * * \\
(.057)\end{array}$ & $\begin{array}{l}.044 \\
(.033)\end{array}$ & $\begin{array}{l}.161 * * \\
(.058)\end{array}$ & $\begin{array}{l}.014 \\
(.033)\end{array}$ & $\begin{array}{l}.153 * * \\
(.058)\end{array}$ \\
\hline STUDENT & & & $\begin{array}{l}.399 * * \\
(.198)\end{array}$ & $\begin{array}{l}.616^{*} \\
(.325)\end{array}$ & $\begin{array}{l}.345^{*} \\
(.197)\end{array}$ & $\begin{array}{l}.587 * \\
(.336)\end{array}$ \\
\hline UNEMPLOYED & & & $\begin{array}{l}-.272 * \\
(.167)\end{array}$ & $\begin{array}{l}-.316 \\
(.378)\end{array}$ & $\begin{array}{l}-.277^{*} \\
(.166)\end{array}$ & $\begin{array}{l}-.368 \\
(.385)\end{array}$ \\
\hline WELFARE & & & $\begin{array}{l}-.249 \\
(.158)\end{array}$ & $\begin{array}{l}-.870 * * \\
(.383)\end{array}$ & $\begin{array}{l}-.212 \\
(.160)\end{array}$ & $\begin{array}{l}-.836 * * \\
(.377)\end{array}$ \\
\hline MARRIED & & & $\begin{array}{l}.155 * * \\
(.071)\end{array}$ & $\begin{array}{l}.165 \\
(.127)\end{array}$ & $\begin{array}{l}.163 * * \\
(.072)\end{array}$ & $\begin{array}{l}.126 \\
(.127)\end{array}$ \\
\hline $\begin{array}{l}\text { LN(HOUSEHOLD } \\
\text { SIZE) }\end{array}$ & & & $\begin{array}{l}-.079 \\
(.061)\end{array}$ & $\begin{array}{l}-.289 * * \\
(.114)\end{array}$ & $\begin{array}{l}-.068 \\
(.062)\end{array}$ & $\begin{array}{l}-.226^{*} \\
(.117)\end{array}$ \\
\hline BLACK & & & $\begin{array}{l}.148^{*} \\
(.080)\end{array}$ & $\begin{array}{l}.093 \\
(.139)\end{array}$ & $\begin{array}{l}.160 * * \\
(.082)\end{array}$ & $\begin{array}{l}.105 \\
(.139)\end{array}$ \\
\hline $\begin{array}{l}\text { HIGH } \\
\text { SCHOOL }\end{array}$ & & & $\begin{array}{l}.501 * * \\
(.108)\end{array}$ & $\begin{array}{l}-.142 \\
(.221)\end{array}$ & $\begin{array}{l}.384 * * \\
(.110)\end{array}$ & $\begin{array}{l}-.252 \\
(.225)\end{array}$ \\
\hline COLLEGE & & & $\begin{array}{l}.473 * * \\
(.120)\end{array}$ & $\begin{array}{l}-.065 \\
(.234)\end{array}$ & $\begin{array}{l}.269^{* *} \\
(.125)\end{array}$ & $\begin{array}{l}-.187 \\
(.243)\end{array}$ \\
\hline $\begin{array}{l}\text { GRADUATE } \\
\text { SCHOOL }\end{array}$ & & & $\begin{array}{l}.435 * * \\
(.125)\end{array}$ & $\begin{array}{l}.103 \\
(.237)\end{array}$ & $\begin{array}{l}.223^{*} \\
(.131)\end{array}$ & $\begin{array}{l}.004 \\
(.245)\end{array}$ \\
\hline $\mathrm{AGE}$ & & & $\begin{array}{l}-.006 * * \\
(.002)\end{array}$ & $\begin{array}{l}.017 * * \\
(.004)\end{array}$ & $\begin{array}{l}-.005 * * \\
(.002)\end{array}$ & $\begin{array}{l}.016^{* *} \\
(.005)\end{array}$ \\
\hline RISK AVERSE & & & & & $\begin{array}{l}.016 \\
(.034)\end{array}$ & $\begin{array}{l}-.051 \\
(.066)\end{array}$ \\
\hline CREDIT CARD & & & & & $\begin{array}{l}.460 * * \\
(.077)\end{array}$ & $\begin{array}{l}.534 * * \\
(.163)\end{array}$ \\
\hline STOCK & & & & & $\begin{array}{l}-.117 * \\
(.069)\end{array}$ & $\begin{array}{l}.176 \\
(.110)\end{array}$ \\
\hline ONLINE & & & & & $\begin{array}{l}.126 * * \\
(.060)\end{array}$ & $\begin{array}{l}-.031 \\
(.099)\end{array}$ \\
\hline INSTITUTIONS & & & & & $\begin{array}{l}.057 * * \\
(.013)\end{array}$ & $\begin{array}{l}-.014 \\
(.021)\end{array}$ \\
\hline $\begin{array}{l}\text { PROFESSIONAL } \\
\text { ADVICE }\end{array}$ & & & & & $\begin{array}{l}.028 \\
(.055)\end{array}$ & $\begin{array}{l}.148 \\
(.096)\end{array}$ \\
\hline
\end{tabular}

** significant at $5 \%$ *significant at $10 \%$ (notes to Table 4 continued on next page) 
Notes to Table 4: (cont.)

Columns 1 and 2, 3 and 4, 5 and 6 are estimated jointly using the Heckman maximum likelihood procedure. Robust standard errors are in parentheses. All estimations include a constant. The dependent variable in columns 1,3 , and 5 is a binary variable indicating savings account ownership. The dependent variable in columns 2,4 , and 6 is the natural log of total savings account balances. 